КОНЦЕПТ ВРШЕЊА СТОМАТОЛОШКЕ ЗДРАВСТВЕНЕ

\title{
THE CONCEPT OF PERFORMING DENTAL HEALTH CARE ACTIVITY WITH A PARTICULAR EMPHASIS ON THE NETWORK OF DENTAL HEALTH CARE INSTITUTIONS IN THE REPUBLIC OF MACEDONIA
}

Kiro Ivanovski, Vlatko Kokolanski, Snežana Peševska

\section{Сажетак}

Системздравствене заштите Републике Македоније перманентно прате негативне појаве и проблеми у сфери организачије. Циљ овог рада је да се укаже на важност адекватног обезбеђивања система стоматолошке здравствене заштите, с посебним освртом на утврђивање мреже стоматолошких здравствених установа у Републици Македонији.

Доношењем Закона о здравственој заштити, који је усвојен 29. марта 2012. године, законодаваи напушта модел трансформачије здравствене делатности путем издавања у закуп простора и опреме и прихвата модел кониесије за вриење стоматолошке делатности у оквиру мреже здравствених установа. На основу овог закона, здравствену делатност у оквиру мреже врше јавне и приватне здравствене установе које ту делатност обављају по принцину конщесије.

Током јуна 2012. године Влада Републике Македоније донела је Уредбу о мрежи здравствених установа. Основни демографски стандард за мрежу примарне стоматолошке заштите је један тим за стоматологију који се састоји од једног изабраног стоматолога и једне стоматолошке сестре на $1.000 \mathrm{cma-}$ новника. Основни демографски стандарди за мрежу секундарне стоматолошке заштите су:

\section{Summary}

The health care system of the Republic of Macedonia is permanently monitored by adverse conditions and issues within the organization sphere. The purpose of this paper is to highlight the importance of adequate provision of the dental health care system, with a particular emphasis on establishing a network of dental health care institutions in the Republic of Macedonia.

By enacting the Law on Health Care, which was adopted on March 29, 2012 the legislator shall abolish the transformation model of health activity through a lease of premises and equipment and shall undertake the concession model for performing dental activity within a network of health care institutions. On the basis of this Law, health activity shall be performed within the network by public and private health institutions. The activity shall be performed according to the principle of concession.

During June 2012, the Government of the Republic of Macedonia has passed a regulation on the network of health institutions. $\mathrm{Ba}$ sic demographic standard for the primary dental care network is one dental team composed of one elected dentist and one dental nurse per 1,000 residents. Basic demographic standards for the secondary dental care network are: one specialist in maxillofacial surgery per 200,000

\footnotetext{
${ }^{1}$ Проф. др Киро Ивановски, Стоматолошки факултет, Универзитет „Св. Кирил и Методиј“, Скопје, Република Македонија.

${ }^{2}$ Мр Влатко Коколански, магистар правних наука и магистрант јавног здравства, Медицински факултет, Универзитет

„Св. Кирил и Методиј“, Скопје, Република Македонија.

${ }^{3}$ Доц. др Снежана Пешевска, Стоматолошки факултет, Универзитет „Св. Кирил и Методиј“, Скопје, Република Македонија.
} 
1 спещијалиста максилофащијалне хирургије на 200.000 становника; 1 специјалиста стоматолошке протетике на 75.000 становника; 1 спечијалиста ортодониије на 8.000 становника; 1 специјалиста оралне хирургије на 100.000 становника; 1 спешијалиста ендодоничие на 200.000 становника; 1 спеичјалиста оралне патологије на $200.000 \mathrm{cma-}$ новника.

На основу анализе постојеће мреже дошли смо дозакључка даје, уз консултащије c релевантним стоматолошким асоцијацијама, потребно још прецизније одредити критеријуме који ће важити за улазак појединих јединица у мрежу стоматолошких здравствених установа, као и критеријуме који се односе на излазак из ње.

Кључне речи: стоматологија, мрежа, организација. citizens; one specialist in dental prosthetics per 75,000 residents; one specialist in orthodontics per 8,000 residents; one specialist in oral surgery per 100,000 residents; one specialist in endodontics per 200,000 residents; one specialist in oral pathology per 200,000 residents.

Based on the analysis of the existing network, we have concluded, in consultation with the relevant dental associations, that it is necessary to determine the criteria more precisely that will be valid for an entry of certain entities within a network of dental health institutions, as well as criteria related to getting out of it.

Key words: dentistry, network, organization.

\section{УВОД}

$\mathrm{Y}$ августу 1991. године, пошто се распала СФРЈ и пошто је Република Македонија постала самостална држава, у овој земљи усвојен је Закон о здравственој заштити. Тим законом уређивала су се права из области здравствене заштите грађана, те права и односи који се тичу здравственог осигурања, поступака у коришћењу здравствене заштите, као и система организације здравствене заштите. Од његовог доношења, па све до ступања на снагу, овај закон био је 13 пута мењан и допуњаван, а Уставни суд је 7 пута поништио, односно укинуо, одређене његове чланове. Године 2000. донет је Закон о здравственом осигурању и на тај начин су престале да важе одредбе Закона о здравственој заштити, уз помоћ којих су дотад била уређивана питања која су се тицала здравственог осигурања. Овим мерама Влада и Министарство за здравство обезбедили су законски оквир за функционисање система, а Фонд за здравствено осигурање (ФЗО) постао је одговоран за наплату доприноса, те за расподелу средстава и за надзирање склапања уговора с даваоцима услуга. ${ }^{1}$

Системздравственезаштитеперманентно прате негативне појаве и проблеми у сфери организације. Ти проблеми повезани су с обимношћу постојећих објеката и с њиховом неравномерном распоређеношћу, као и с питањима која се односе на њихову рационализацију, смањивање прекобројног медицинског кадра у здравственом сектору и обезбеђивање одрживог финансирања превентивних програма и капиталних инвестиција. ${ }^{2}$ Због свега овога неминовно је било да се приступи реформама система здравствене заштите, укључујући ту и стоматолошку струку.

\section{ЦИЉ РАДА}

Циљ овог рада је да се укаже на важност адекватног обезбеђивања система стоматолошке здравствене заштите, с посебним освртом на утврђивање мреже стоматолошких здравствених установа у Републици Македонији. 


\section{ТРАНСФОРМАЦИЈА \\ (ПРИВАТИЗАЦИЈА) \\ СТОМАТОЛОШКИХ \\ ЗДРАВСТВЕНИХ УСТАНОВА ПУТЕМ ЗАКУПА}

Године 2004, на основу измена и допуна Закона о здравственој заштити, приступило се трансформацији делатности које се тичу примарне здравствене заштите из области медицине, те комплетне стоматолошке и фармацеутске здравствене делатности и то путем издавања у закуп простора и опреме здравственим радницима који су радили у тим здравственим јединицама, с циљем оснивања приватних здравствених установа. У овом случају није дошло до класичне промене власништва, већ се извршило приватизовање јавне услуге. У јавним установама у закуп су се давали простор и опрема делова који представљају просторну, техничку и функционалну целину - под условом да се оснива приватна здравствена установа за вршење одговарајуће делатности. Носиоци стоматолошке здравствене делатности у здравственим установама могу бити само лица са свршеним Стоматолошким факултетом, окончаним периодом пробног рада, положеним стручним испитом и с лиценцом за обављање посла. ${ }^{3}$ Радне лиценце издаје Стоматолошка комора Македоније, на основу јавно-правног овлашћења, које ова институција поседује.

У току 2005. године успоставио се нов систем финансирања примарне стоматолошке заштите на основу увођења капитације. ${ }^{4}$ Капитација је потенцијални месечни износ надокнаде који се изабраном стоматологу, односно здравственој установи, исплаћује ради обезбеђивања услуга осигураницима. ${ }^{5}$ У то време сматрало се ,да су уз помоћ овог метода плаћања постигнути позитивни резултати, односно, да су пацијенти боље збринути, те да се стимулише ефикасност у послу и да се спроводи боља контрола трошкова у здравственим установама“" . Међутим, једно истраживање које смо спровели показује да су стоматолози незадовољни износом капитације и циљевима предвиђеним у уговорима са $Ф 30 .{ }^{7}$

На основу аката Фонда, здравственим услугама у специјалистичко-консултативној стоматолошкој здравственој заштити сматрају се обављене услуге из области протетике, ортодонције и оралне хирургије. ${ }^{8}$ На основу тога ФЗО, у оквирима специјалистичке стоматологије и склапа уговоре са стоматолозима-специјалистима из области ортодонције, протетике и оралне хирургије. Начин плаћања у специјалистичкој стоматолошкој здравственој заштити врши се на основу пружених здравствених услуга.

Једина делатност на секундарном нивоу у стоматологији која обухвата боравак и третман у болници је максилофацијална хирургија. Ипак, имајући у виду да се овде током вршења здравствених услуга тражи стручан, те (с организационе и с технолошке тачке гледишта) сложен и мултидисциплинаран здравствени третман, ова делатност најчешће се обавља на терцијалном нивоу здравствене заштите.

\section{КОНЦЕСИЈЕ ПРЕДВИЪЕНЕ ЗАКОНОМ О ЗДРАВСТВЕНОЈ ЗАШТИТИ (МАРТ 2012) И ФОРМИРАЊЕ МРЕЖЕ}

Доношењем Закона о здравственој заштити, који је усвојен 29. марта 2012. године, законодавац напушта модел трансформације здравствене делатности путем издавања у закуп простора и опреме и прихвата модел концесије за вршење стоматолошке делатности у оквиру мреже здравствених установа. На основу овог закона, здравствену делатност у оквиру мреже врше јавне и приватне здравствене установе које ту делатност обављају по принципу концесије. Здравствену делатност ван мреже врше приватне здравствене 
установе под условима предвиђеним законом, а ова делатност финансира се на основу тога што пацијенти личним средствима плаћају извршене здравствене услуге. Законодавац искључује примену прописа из области концесија и других врста јавно-приватног партнерства које су уређене посебним законом (реч је о Закону о концесијама и јавно-приватном партнерству) и одлучује да концесионерство у здравственој делатности регулише Законом о здравственој заштити ${ }^{9}$ усвајајући овај закон као lex specialis.

Стоматолошка комора, као професионално удружење, и друге институције система препознале су одавно потребу за адекватним утврђивањем мреже здравствених установа. Сугерисало се, међутим, и на обазривост приликом успостављања критеријума за њено утврђивање, нарочито кад је реч о уласку у мрежу и о изласку из ње.

Током јуна 2012. године Влада Републике Македоније донела је Уредбу о мрежи здравствених установа. ${ }^{10}$ На основу те уредбе, мрежом се на нивоу примарне здравствене заштите одређује максималан број тимова који могу функционисати у оквиру примарне здравствене заштите за одређени статистички регион. Основни демографски стандард за мрежу примарне стоматолошке заштите је један тим за стоматологију који се састоји од једног изабраног стоматолога иједне стоматолошке сестре на 1.000 становника. ${ }^{10}$

Актуелни и максимални број тимова у оквиру примарне стоматолошке здравствене заштите који су предвиђени мрежом стоматолошких установа приказани су на графикону 1. Из приложеног се види да је актуелни број стоматолошких тимова у примарној здравственој заштити мањи од максималног предвиђеног броја.
Графикон 1: Мрежа тимова у делатности стоматолошке здравствене заштите на нивоу примарне здравствене заштите (актуелни и максимални број).

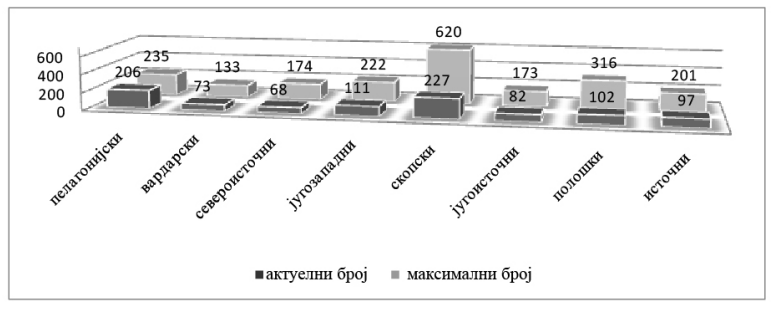

Извор: Уредба о мрежи здравствених установа $a^{10}$

Кад је реч о спровођењу специјалистичкоконсултативне, дијагностичке и болничке здравствене делатности, мрежом се на нивоу секундарне и терцијарне здравствене заштите одређују максималан број специјалиста по делатностима и број кревета по одређеним делатностима у оквиру болничких здравствених установа на нивоу секундарне здравствене заштите, структура терцијарне здравствене заштите, као и максималан број одређених услуга на нивоу региона или на нивоуРепублике Македоније. Основни демографски стандарди за мрежу секундарне стоматолошке заштите су: 1 специјалиста максилофацијалне хирургије на 200.000 становника; 1 специјалиста стоматолошке протетике на 75.000 становника; 1 специјалиста ортодонције на 8.000 становника; 1 специјалиста оралне хирургије на 100.000 становника; 1 специјалиста ендодонције на 200.000 становника; 1 специјалиста оралне патологије на 200.000 становника. ${ }^{10}$

На графикону 2. приказан је актуелни и максимални број специјалиста у оквиру секундарне стоматолошке здравствене заштите на националном нивоу, по областима. Приметно је да актуелни и максимални број специјалиста нису усаглашени. 
Графикон 2: Мрежа специјалиста у оквиру секундарне стоматолошке заштите на националном нивоу (актуелни и максимални број).

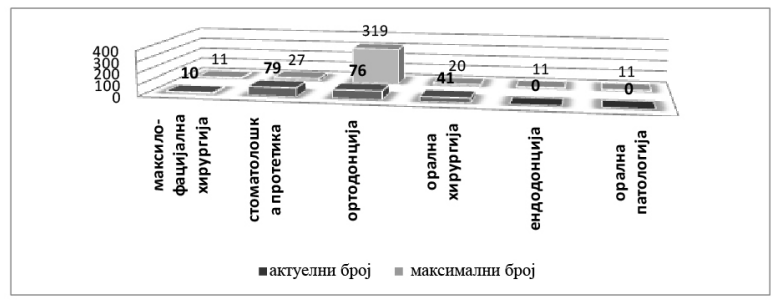

Извор: Уредба о мрежи здравствених установа ${ }^{10}$

У овом тренутку законска препрека у вези са склапањем уговора с Фондом за здравствено осигурање постоји кад је реч о специјалностима: ендодонција и орална патологија. До ове ситуације дошло је због тога што ФЗО у претходном периоду није склапао уговоре с њима. Управо због тога што стоматолози знају да, пошто евентуално претходно заврше специјализацију, ипак неће бити у могућности да раде као специјалисти, ретко се дешавало (а и у будућности ће се тешко моћи очекивати да се нешто тако деси) да добијемо специјалисте из ових области у оквиру нашег здравственог система.

\section{АКТУЕЛНО СТАЫЕ}

У новембру 2012. године, осам месеци пошто је усвојен, Закон о здравственој заштити био је измењен и допуњен. Увођењем измена и допуна Закона о здравственој заштити, законодавац напушта модел концесије за вршење стоматолошке делатности у мрежи здравствених установа. Уместо тога, прихвата се модел додељивања лиценце. Концесије додељене на основу Закона о здравственој заштити (Службен весник на Република Македонија, број 43/12) и прописи који су на основу њега донети сматрају се лиценцама, с роком важности који је у сагласности с прописима који су тада важили. Поступак за додељивање лиценце води Министарство за здравство. 9 Сви подзаконски прописи који су били усвојени на основу претходног закона (оног из марта исте године) претрпели су измене у односу на модел вршења стоматолошке делатности. Разлог због којег је Влада предложила замену појма „концесија“ појмом „лиценца““ у тексту читавог закона лежи у чињеници да се одредбе Закона о концесијама и о јавноприватном партнерству којима се уређује поступак за добијање концесије и статуса јавно-приватног партнерства односе на концесије које немају заједничких карактеристика с додељивањем концесија за вршење здравствене делатности у мрежи здравствених установа, па се тако законодавац ограђује од могућности да у пракси дође до употребе истог појма с различитом наменом.

\section{ЗАКЈУУЧА}

На основу прегледа који смо овде изложили, можемо закључити да се здравствено законодавство у Републици Македонији стално мења. Узрок овоме су константни проблеми с којима је суочена стоматологија као делатност, али и здравство у целини. Важно је, такође, истаћи и то да промене у законодавству произилазе и из неконзистентности здравствених стратегија које усвајају, у политичком смислу, различите власти. На основу анализе постојеће мреже, дошли смо до закључка да је, уз консултације с релевантним стоматолошким асоцијацијама, потребно још прецизније одредити критеријуме који ће важити за улазак појединих јединица у мрежу стоматолошких здравствених установа, као и критеријуме који се односе на излазак из ње. 


\section{ЛИТЕРАТУРА}

1. Давитковски Б, Караџинска-

Бислимовска J, Спасовски М, Чакар 3, Косевска Е, Тупанчевски Н, и сор. Право и јавно здравство. Правен факултет „Јустинијан I“, Скопје, 2009; 43-52.

2. Купев М. Новиот кониелт за вршењье на здравствена дејност во мрежата на здравствените установи со посебен осврт на определувањето на кониесија и на кониесионерите. Vox medici 2012; 76: 38-41.

3. Закон за здравствена заштита. „Службен весник на Република Македонија", број 38/91, 46/93, 55/95, 10/2004, 84/2005, 111/2005, 65/2006, 5/2007, 77/2008, 67/2009, 88/10, 44/11 и $53 / 11$.

4. Gjorgjev D, Bacanovic A, Cicevalieva S, Sulevski Z, Grosse-Tebbe S. The former Yugoslav Republic of Macedonia: Health system review. Health Systems in Transition, 2006; 8(2): 74.

5. Правилникот за начинот на плаќање на здравствени услуги во примарната стоматолошка заштита. „Службен весник на Република Македонија”, број 42/2012.

6. Фонд за здравствено осигурување на Македонија. Годишен извештај 2006. за работењето на Фондот за здравствено осигурување на Македонија. Скопје, 2007.

7. Коколански В. Правна регулащија на стоматологијата како дејност (магистерски труд). Скопје, Правен факултет „Јустинијан I“, 2012.

8. Правилник за критериумите за склучување договори и за начинот на плаќање на здравствените услуги на здравствените установи кои вршат специјалистичко-консултативна стоматолошка здравствена заштита. „Службен весник на Република Македонија”, број 52/2007, 104/2012.

9. Закон за здравствената заштита. „Службен весник на Република Македонија", број 43/2012, 145/2012.

10. Уредба за мрежа на здравствени установи. „Службен весник на Република Македонија”, број 81/2012.

Контакт: Проф. др сц. Киро Ивановски, Универзитет „Св. Кирил и Методиј”, Стоматолошки факултет, Скопје, Република Македонија, адреса: Водњанска бр. 17., тел. +38971260314, e-mail: kiroivanovski@stomfak.ukim.edu.mk 